\title{
Factors Affecting Neonatal Hearing Screening Follow-up in Developing Countries: One Insitution Prospective Pilot Study
}

\author{
Gelişmekte Olan Ülkelerde Yenidoğan İşitme Taraması Takibini \\ Etkileyen Faktörler: Bir Kurumda Prospektif Pilot Çalışması
}

\author{
Nermin HRNCIC $\bullet$, Amna GOGA $\odot$, Selma HRNCIC $\bullet$, Haris HATIBOVIC $\odot$, Djenad HODZIC $\odot$
}

Ethics Committee Approval: This study was approved by Cantonal Hospital Zenica Ethics Committee, 26 January 2016, 20/1-2-491/2-2

Conflict of interest: The authors declare that they have no conflict of interest.

Funding: None.

Informed Consent: Informed consent was taken from the participants of the study.
Cite as: Hrncic N, Goga A, Hrncic S, Hatibovic H, Hodzic D. Factors affecting neonatal hearing screening follow-up in developing countries: one insitution prospective pilot study. Medeni Med J. 2021;36:14-22.

\begin{abstract}
Objective: To detect factors related with loss to follow-up (LTF) in neonatal hearing screening (NHS) program of one institution in a developing country.

Methods: A prospective study was planned based on the data collected in a pilot study conducted a year before in the same institution. In this pilot study, hearing screening was performed before hospital discharge for every infant (1217 newborns) in six months period. Total referral rate was $19.1 \%(223 / 1217)$. Loss to follow-up (LTF) was 38.1\% (85/223). Telephonic interviews were done with 50 parents who had not come with their child to the second hearing test. For these telephonic interviews the questionnaire with four sections (socio-demographic information; information about pregnancy, birth, and present health condition of the child; caregiver knowledge of neonatal hearing screening, and reasons for default on follow-up) was created. Results: The mothers participated in this study were 29.1 years $( \pm 5.2$ SD) of age in average. Place of residence was mostly rural $(64 \%$; $n=32)$ with $39.4 \mathrm{Km}( \pm 24.8 \mathrm{SD})$ away from from the rescreen referral center. Their knowledge on neonatal hearing screening, hearing impairment incidence or treatment opportunities was at a very low level. Caregivers' perceptions that follow-up was unnecessary (50\%; $n=25)$, was most frequently given reason for follow-up default, followed by newborns bad health condition $(12 \% ; n=6)$ and forgetting about the follow-up visits $(8 \% ; n=6)$.

Conclusion: The main reason for default in follow-up in our study was caregiver's poor knowledge about this topic.
\end{abstract}

Keywords: Neonatal screening, follow-up, developing countries, early detection, otoacoustic emissions

Öz

Amaç: Gelişmekte olan bir ülkede hastane tabanlı bir yenidoğan işitme taraması (NHS) programında takip kaybı (LTF) ile ilişkili anne ve bebek faktörlerini belirlemektir.

Yöntem: Aynı kurumda bir yıl önce yapılan pilot çalışma verileriyle ileriye dönük bir çalışma planlanmıştır. Bu pilot çalışmada, altı aylık dönemde her bebeğe (1217 yenidoğan) hastaneden taburcu edilmeden önce issitme taraması yapılmıștır. Toplam sevk oranı \%19,1 (223/1217) idi. Takip kaybı (LTF) \%38,1 (85/223) idi. İkinci işitme testine çocuklarıla gelmeyen 50 ebeveyn ile telefon görüşmesi yapılmıştır. Bu telefon görüşmeleri için dört bölümlü (sosyo-demografik bilgiler; hamilelik, doğum ve mevcut sağık durumu hakkında bilgiler; bakım verenin yenidoğan işitme taraması bilgisi ve takipte gecikme nedenlerinden oluşan) bir anket hazırlanmıştır. Bulgular: Katılımcılar yas ortalaması 29,1 ( $\pm 5,2$ SD) olan annelerdir. Ikamet yeri coğunlukla kırsaldır (\%64; $n=32)$ ve yeniden tarama sevk merkezine ortalama $39,4 \mathrm{~km}( \pm 24.8 \mathrm{SD})$ uzaklıktadır. Yenidoğan işitme taraması, işitme bozukluğu insidansı veya tedavi firsatları hakkındaki bilgilerinin çok düsüuk olduğu bulunmuștur. Takip kaybı için en sık ifade edilen nedenler, bakım verenlerin takibin gereksiz olduğu yönündeki algıları (\%50; $n=25)$, çocuğun sağlık durumunun kötü olduğu gerekçesi $(\% 12 ; n=6)$ ve takibin unutulmasıdır $(\% 8 ; n=6)$.

Sonuç: Çalışmamızda takipte kayıplar oluşmasının ana nedeni bakım verenin bu konudaki yetersiz bilgisi olarak ortaya çıkmıştır.

Anahtar kelimeler: Yenidoğan taraması, takip, gelişmekte olan ülkeler, erken teşhis, otoakustik emisyonlar

( ) Copyright Istanbul Medeniyet University Faculty of Medicine. This journal is published by Logos Medical Publishing.

Licenced by Creative Commons Attribution-NonCommercial 4.0 International (CC BY-NC 4.0)
Received: 4 December 2020

Accepted: 7 February 2021

Online First: 26 March 2021

Corresponding Author:

N. Hrncic

ORCID: 0000-0001-7581-9430

Cantonal Hospital

Zenica, Bosnia and Herzegovina

nhrncic@yahoo.de

A. Goga

ORCID: 0000-0002-3609-7436

H. Hatibovic

ORCID: 0000-0001-7321-4710

D. Hodzic

ORCID: 0000-0002-0213-5625

Cantonal Hospital

Zenica, Bosnia and Herzegovina

S. Hrncic

ORCID: 0000-0002-7699-5900

Public Health Center

Zenica, Bosnia and Herzegovina 


\section{INTRODUCTION}

In comparison with other congenital malformation for which treatment can be provided, hearing impairment has the highest incidence of at least $1 / 1000$ and in some studies $6 / 1000^{4}$ or even $8 / 1000^{5}$ newborns with high degree hearing impairment or deafness ${ }^{1-3}$. Deafness or bad hearing can lead to poor cognitive and language development, behavioral and social adjustment, and academic success ${ }^{6,7}$. The chance of optimizing a child's potential in speech and language development increases if hearing loss is detected and intervention is done in very early age $\mathrm{e}^{2,8}$. In Joint Committee in Infant Hearing and The first European Consensus Development Conference on Neonatal Hearing Screening, screening of all infants prior to one month of age was recommended ${ }^{9,10}$. The Centers for Disease Control and Prevention (CDC) in the USA and Early Hearing Detection and Intervention (EHDI) program published universal goals for early detection and intervention of hearing loss. The first three goals were later popularized as a 1-3-6 plan. It was planned to screen all newborns by one month of age, to have diagnosis by three months, and to start with therapy/intervention at the age of six months for all diagnosed infants ${ }^{11}$. States that achieve the 1-3-6 goal should try to meet a 1-2-3-month timeline ${ }^{10}$. The effectiveness of universal neonatal hearing screening (UNHS) has been proven by the reduction in age of diagnosis and age of hearing aid fitting since UNHS was first implemented $^{12-14}$.

Along with the lack of NHS coverage, the failure of parents to bring their children for following hearing control examination after first NHS referral results also contributes to delayed detection and intervention of hearing impairment ${ }^{15}$. Active parental support for UNHS and early identification and intervention programs are crucial for successful developmental outcome for the affected children ${ }^{16}$. It was found that follow-up is the most difficult part of a NHS program, especially in early years of program implementation ${ }^{17}$ in which many programs break down ${ }^{18}$. Although problematic follow-up of newborns in NHS programs are more frequently seen in developing countries, developed countries are also struggling with the same problem ${ }^{15}$.

In implementation process of two stage UNHS in our institution with main goal to achieve 1-3-6 plan of hearing impairment detection and intervention, we already did some pilot studies. During those pilot studies, we noticed higher rates of loss to follow-up (LTF) and we decided to do research to find main reasons for that.

\section{METHODS}

Institutional Ethics Committee approval for this study was obtained on January 26, 2016 (No 20/1-2-491/2-2), before any data collection commenced. One of our pilot studies was done between February and August 2016. In this six months, we screened for hearing impairment every infant born in our institution with Transient Evoked Otoacoustic Emission (TEOAE) tests. A brand new interacoustic device "Titan" (Interacoustics A/S, Denmark) was used for screening of all infants. Total of 1217 infants (2434 ears) were screened. In Well-baby Nursery (WBN) $76.4 \%(930 / 1217)$ and in Neonatal Intensive Care Unit (NICU) 23.6\% 287 (Total referral was $19.1 \%$ (223/1217 infants), in NICU $21.9 \%$ $(63 / 287)$ and in WBN $17.2 \%(160 / 930)^{19}$. All of those 223 newborns were referred to a next hearing examination (rescreening) in two to four weeks. Eleven months after this pilot study had been completed, the review of data was done and it was found that $38.1 \%(85 / 223)$ infants were lost to follow-up (LTF), $27.1 \%(23 / 85)$ in NICU and $72.9 \%(62 / 85)$ in WBN (Table 1$)$.

A prospective telephonic interview with parents who defaulted a follow-up (did not bring their children to follow-up hearing test) was done. We interviewed with the parents (mothers) that we 
managed to get on the phone. Telephone numbers were taken from the infant records. All interviews were done from the official hospital phone number on weekdays between 16:30 and 19:30. Before the interview was commenced, informed consent was obtained verbally from caregivers. For this telephonic interview, the questionnaire with four sections (socio-demographic information; information about pregnancy, birth and present health condition of the child; caregiver knowledge of NHS, and reasons for default on follow-up) composed of $\mathbf{2 0}$ questions in total was created. The researcher conducted all interviews, which lasted seven minutes on average $( \pm 1.7 \mathrm{SD})$ with a range of four minutes minimally to a maximum of 11.5 minutes. Telephonic interviews were done with $58.8 \%(50 / 85)$ caregivers. Another three caregivers (3.53\%) that we had got on the telephone refused to be interviewed. We could not get on the telephone with the remaining 37.6\% (32/85) of the caregivers. Among participating caregivers, 28\% (14/50) were parents of the children who were in NICU because of different indications (Table 2) and remaining 72\% $(36 / 50)$ were parents of healthy children from

Table 1. Overview of the study participants.

\begin{tabular}{lrlll}
\hline $\begin{array}{l}\text { Total } \\
\text { N (\%) }\end{array}$ & $\begin{array}{l}\text { Refered } \\
\text { N (\%) }\end{array}$ & $\begin{array}{l}\text { LTF } \\
\mathbf{N}(\%)\end{array}$ & $\begin{array}{l}\text { Interviewed } \\
\text { of LTF } \\
\mathbf{N}(\%)\end{array}$ \\
\hline WBN & $930(76.40)$ & $160(17.20)$ & $62(38.75)$ & $36(58.10)$ \\
NICU & $287(23.60)$ & $63(21.90)$ & $23(36.51)$ & $14(60.90)$ \\
Total & $1217(100)$ & $223(18.32)$ & $85(38.12)$ & $50(58.82)$
\end{tabular}

WBN: Well-Baby Nursery, NICU: Neonatal Intensive Care Unit, LTF: Lost to Follow-up

Table 2. Indications for referrals to the neonatal intensive care unit (NICU).

\begin{tabular}{lcc}
\hline Indications & N & $\%$ \\
& & \\
Low birth weight & 5 & 35.8 \\
Asphyxia & 5 & 35.8 \\
Prematurity & 1 & 7.1 \\
Vacuum delivery & 1 & 7.1 \\
Mother's health condition & 1 & 7.1 \\
Unknown & 1 & 7.1 \\
Total & 14 & 100 \\
& & \\
\hline
\end{tabular}

WBN and without risk factors for hearing impairment. All infants were born and screened in this six-month period (February-August 2016) during above-described pilot study. All telephonic interviews were performed between $21^{\text {st }}$ of June and $5^{\text {th }}$ July 2017.

\section{Data Management and Analysis}

Responses were recorded on data collection forms and transferred to electronic Microsoft Excel database before being analyzed using the statistical package IBM-SPSS version 20.0. Standard descriptive methods of statistics were used. Percentage and chi square calculations, and binomial tests were employed for data analysis. For all analyses, a p-value of $<0.05$ was accepted as statistically significant.

\section{RESULTS}

\section{Demographics}

Participants were mothers with a mean age of 29.1 years $( \pm 5.2 \mathrm{SD})$. A statistically significantly greater number of respondents were mothers whose children were placed in the Well-baby Nursery (WBN) after birth (WBN group), compared to surveyed mothers whose children were placed in the Intensive Care Unit (NICU) after birth (NICU group) (binomial test $\mathrm{p}=0.003$ ). We did not attribute much importance to this intergroup difference when we considered the comparable percentages of children who were lost to followup in both groups $(38.75 \%$ for WBN and $36.12 \%$ for NICU). Indeed, we managed to survey almost the same percentage of parents from both groups (36/62 or $58.1 \%$ for $W B N$ and $14 / 23$ or $60.9 \%$ for NICU) (Table 1).

Surveyed families were living in rural (64\%; $\mathrm{n}=32$ ), and urban ( $36 \% ; \mathrm{n}=18$ ) areas. A borderline statistically significant difference was noted between the number of respondents who were living in rural areas compared with those living in the city (binomial test $\mathrm{p}=0.066$ ). No statistically significant difference was found in the number of 
respondents with respect to their places of residence (rural or urban) between WBN and NICU groups was found (chi-square test $\mathrm{p}=0.495$ ).

Average distance from the rescreen referral center was $39.4 \mathrm{~km} \mathrm{(} \pm 24.8 \mathrm{SD}$ ) (range: 10 to $90 \mathrm{~km})$. Only $25 \%$ of the respondents lived at a distance of more than $51.25 \mathrm{~km}$ from the referral center for a hearing check-up. While $50 \%$ of the respondents lived at a distance of $43 \mathrm{~km}$ from the referral center.

Education levels were elementary school, high school, and university in $14 \%(n=7) ; 58 \%(n=29)$; $28 \%(n=14)$ of the participating mothers, respectively. Statistically significantly greater number of surveyed mothers had completed high school, when compared with those that completed only primary school or university (chi-square test $p=0.001$ ). There was no statistically significant difference regarding the level of education of the surveyed mothers between groups of WBN, and NICU (chi-square test $\mathrm{p}=0.586$ ).

Both parents were employed in $34 \%(n=17)$, only father was employed in 58\% $(n=29)$ of interviewed families, and in $8 \%(n=4)$ of the families both parents were unemployed. There was no family in which only the mother was employed. Therefore, a statistically significant difference among the surveyed families, was noted depending on the employment status of the parents (chisquare test $p<0.001$ ). When the groups of WBN and NICU were compared no significant difference in the employment status of the parents was found (chi-square test $\mathrm{p}=0.367$ ).

Participants estimated their total monthly household income as low, average, and high in $16 \%$ $(n=8), 76 \%(n=36)$, and $8 \%(n=4)$ of the families respectively. Compared to the surveyed families that rated their monthly income as low or high, most of the families statistically significantly more often rated their monthly income as average (chisquare test $p<0.001)$. There was no statistically significant difference groups of WBN and NICU) (chi-square test $\mathrm{p}=0.400$ ).

\section{Pregnancy, Birth, and Present Health Condition of the Child}

It was the first child of $42 \%(n=21)$, and second, third or fourth child in $46 \%(n=23), 8 \%(n=4)$ and $4 \%(n=2)$ of the participants, respectively. Surveyed parents had mostly their first or second child rather than their third or fourth child with a statistically significantly proven difference among groups (chi-square test $\mathrm{p}<0.001$ ). Any statistically significant difference was not observed between groups of WBN, and NICU (chi-square test $\mathrm{p}=0.413$ ).

Prematurity was reported in $8 \%(n=4)$ of the cases. There were many more term births than preterm infants (binomial test $\mathrm{p}<0.001$ ). All preterm infants were from NICU group and there was no preterm infants in WBN group (chi-square test $\mathrm{p}=0.001$ ).

Natural birth occurred in $72 \%(n=36)$ of the mothers, and C-section was performed in $28 \%(n=14)$ of the cases. Significantly more surveyed mothers had natural childbirth in total sample (binominal test $p=0.003$ ). In NICU group, significantly greater number of surveyed mothers underwent cesarean section compared to WBN group (chi-square test $\mathrm{p}=0.004)$.

Complications during pregnancy were reported in $14 \%(n=7)$ of interviewed mothers (high blood pressure, cardiac arrhythmia in the mother, suspected Down Syndrome, etc.). A significantly higher number of surveyed mothers did not have any problems in pregnancy (binomial test $p<0.001$ ). The difference in complications during pregnancy between WBN and NICU groups had a borderline significance (chi-square test $\mathrm{p}=0.064$ ).

There were complications in delivery reported in $10 \%(n=5)$ of the cases (rupture of the uterus, birth by vacuum, and fracture of the clavicle of the 
baby). Complications during childbirth were reported by only a few surveyed mothers with a statistically significantly proven intergroup difference (binomial test $\mathrm{p}<0.001$ ). Childbirth complications were not significantly more common in any of the groups compared (NICU and WBN) (chi-square test $\mathrm{p}=0.093$ ).

Referrals for both ears were noted in 22\% ( $n=11)$ and for one ear in $78 \%(n=39)$ of the children (right $24 \%$ or $n=12$; left $54 \%$ or $n=27$ ). One ear was retested more frequently than both ears (chisquare test $\mathrm{p}=0.008$ ).

At the time of interview, the children were 13.9 months old in average $( \pm 1.9 \mathrm{SD})$. The youngest was 11 and the oldest 18 months of age. All mothers had estimated good hearing and no other serious health problems in their children.

\section{Caregiver's Knowledge about the Topic}

Knowledge of the participants about NHS, incidence of hearing impairment or treatment opportunities were at a very low level (Table 3 ). There was no significant difference in the number of surveyed mothers who did and did not know what NHS was (binomial test $p=0.322$ ). All of them who knew what NHS means told us that they first heard about the NHS from us when their baby was screened. No statistically significant difference in NHS knowledge was observed between both groups (WBN and NICU) (chi square test $\mathrm{p}=0.574)$.

Table 3. Knowledge of the participants about NHS, incidence of hearing impairment or treatment opportunities.

\begin{tabular}{lcc}
\hline Questions & $\begin{array}{l}\text { Yes } \\
\text { N (\%) }\end{array}$ & $\begin{array}{l}\text { No } \\
\text { N (\%) }\end{array}$ \\
\hline $\begin{array}{l}\text { Do you know what NHS is? } \\
\begin{array}{l}\text { Do you know the incidence of hearing } \\
\text { impairment? }\end{array}\end{array}$ & $\begin{array}{c}21(42) \\
2(4)\end{array}$ & $\begin{array}{c}29(58) \\
48(96)\end{array}$ \\
$\begin{array}{l}\text { Do you know if any treatment can help } \\
\text { children with hearing loss? }\end{array}$ & $30(60)$ & $20(40)$ \\
$\begin{array}{l}\text { Do you know what cochlear implant is? } \\
\text { Do you support NHS? }\end{array}$ & $14(28)$ & $36(72)$ \\
& $50(100)$ & $0(0)$ \\
\hline
\end{tabular}

NHS: Newborn Hearing Screening
A small number of surveyed mothers knew the incidence of deafness in newborn babies (binomial test $p<0.001$ ) without any statistically significant difference between the groups of NICU and WBN (chi square test $\mathrm{p}=0.368$ ).

All caregivers $(100 \% ; n=50)$ indicated that they supported hearing screening, but only $34 \%$ of them $(n=17)$ believed that there were effective treatments and interventions for infants born with a permanent hearing loss. Remaining 60\% $(n=30)$ thought that no treatment was available while $6 \%$ $(n=3)$ were unsure. A significant difference between the surveyed mothers in terms of knowledge of therapeutic options for deaf children was noted (chi square test $p<0,001$ ). The surveyed mothers in NICU group showed a significantly higher level of knowledge about therapeutic options for deaf children compared to the surveyed mothers in WBN group (chi square test $\mathrm{p}=0.013$ ).

Only $28 \%(n=14)$ knew what cochlear implant $(\mathrm{CI})$ was. Significantly more surveyed mothers did not know what a cochlear implant was (binomial test $p=0.003$ ). Any statistically significant difference was not detected between the groups of NICU, and $\mathrm{WBN}$ as for being knowledgeable about cochlear implants (chi square test $\mathrm{p}=0.519$ ).

\section{Reasons for Default in Follow-up}

Most frequently given reasons for follow-up default were caregivers' perceptions that follow-

Table 4. The reasons given for follow-up default.

\begin{tabular}{lrr}
\hline Reasons & N & $\%$ \\
\hline We thought it was not necessary & 25 & 50 \\
We forgot & 4 & 8 \\
Control was not recommended & 4 & 8 \\
We could not come because of work and other & 3 & 6 \\
obligations & 2 & 4 \\
Too far from the hospital & 1 & 2 \\
We had no transportation means & 1 & 2 \\
We did not have any money for transportation & 6 & 12 \\
The child was sick & 4 & 8 \\
Something else & 50 & 100 \\
Total & & \\
\end{tabular}


up was unnecessary $(50 \%, \mathrm{n}=25)$, their child was in serious health condition $(12 \%, n=6)$, and the fact that they had forgotten about the follow-up $(8 \%, n=6)$ (chi square test $\mathrm{p}<0.001$ ) (Table 4$)$.

Despite their follow-up default, majority of the participating mothers $(60 \%, n=30)$ reported that they were very disturbed in the moment we told them to bring their newborn to hearing control (rescreening). No statistically significant difference in the total sample was found (binomial test $p=0.203$ ). In terms of concerns among the surveyed mothers, we did not find statistically significant difference between NICU and WBN groups (chi square test $\mathrm{p}=0.797$ ).

\section{DISCUSSION}

Despite all proven advantages of Universal Neonatal Hearing Screening (UNHS) for best treatments of children with hearing impairment $t^{8,20,21}$, UNHS is still not implemented in hospitals in our country. Also, NHS is still not mandated or legislated. The lack of legislation along with absence of awareness of the significance of NHS typically delays initial detection of hearing loss with average ages of first diagnosis ranging from 23 to 42 months of age $e^{22,23}$. As a developing country, our country has no data about NHS coverage or percent of newborns participating in NHS. There is also no unique NHS protocol for all birth centers in the country. Screening all newborns is performed in some centers, some of them perform screening tests for hearing only for newborns with risk factors for developing hearing impairment and some centers have no NHS protocol at all.

Total "referral" result at the first hearing test in this study was $19.1 \%$ which was much higher than $5 \%$ recommended in the literature ${ }^{24}$. The reason for such a result may be an early discharge of newborns from the hospital which is forcing us to make the first hearing test of NHS too early ${ }^{25}$. It is known that OAE method is very sensitive to barriers in the middle ear (amniotic fluid) and external ear (vernix). If hearing tests have been done too early, likelihood of getting false- positive results (referral) would be higher due to these barriers in the ear canal or middle ear of the newborn with intact hearing in reality ${ }^{26}$. In all cases of "referral" results of the first hearing test, we are obliged to refer the newborn to a control auditory examination which imposes additional financial burden on the parents attending NHS program and its complete and efficient implementation becomes difficult. Subsequently, increased number of newborns will not be taken to the hearing check. In this study, majority of the referred children had to be retested only on one ear and it was noted as statistically significant. It is possible that the parents did not consider the situation to be serious and therefore, they decided not to bring the child for a control hearing test. The effectiveness of NHS program, whose primary goal is to find newborn babies with high hearing threshold in time for timely intervention, is reduced in this way ${ }^{20}$.

In this study, $38.1 \%$ of the newborns for whom control hearing test were recommended were not tested because of their absenteeism. Some reports from other developing countries have indicated inadequate attendance to follow-up visits $^{27}$. LTF rate of $43 \%$ in Malaysia and $66 \%$ in Pakistan were reported in UNHS pilot study after the first stage of screening ${ }^{28,29}$. Most common causes of LTF at rescreening are low socioeconomic status, social risk factors, accessibility to follow-up facilities, having multiple children and having no babysitter/family member to care for the children left at home, having no time off from work, financial burdens imposed by travel on the facilities, lack of understanding about importance of rescreening, and mothers' level of education ${ }^{18,30,31}$. In the USA, almost $94 \%$ of newborns who needed hearing control came to control testing, and only 6-7\% of newborns were lost to follow-up in the United States ${ }^{32}$. A response rate of $85 \%$ or LTF rate of $15 \%$ in the literature is 
considered satisfactory ${ }^{33}$. The results of previous study cannot be considered satisfactory with $38.1 \%$ of newborns who were lost to follow-up. As an extremely important issue, this study attempted to understand the reasons for default of newborn children on the second hearing test. The intention was to identify the reasons for newborns' failure to attend the second hearing test and to try to find solutions which would decrease LTF rates. Any reduction in the number of newborns that are lost to follow-up increases the quality and efficiency of NHS program. In this way, the costs of NHS program itself would also be reduced.

The most common reasons for parental decisions not to bring their newborn to a second hearing test scheduled in the survey were lack of information and knowledge of parents/guardians about the importance of NHS for their children. The parents' knowledge about NHS, and the incidence of hearing loss in newborns and the possibilities of rehabilitation/habilitation in this study were at a very low level. Even $50 \%$ of the surveyed parents considered that a hearing control for their newborn was not needed. Awareness of the parents/ guardians and their knowledge about NHS are very important for successful implementation of NHS in our institution. In one study that looked at the problem from the perspective of parents, 99\% of mothers said they needed more information about the NHS. Only parents aware of the issues dealt with by NHS were well cooperat$\mathrm{ed}^{34}$.

In $12 \%$ of the cases poor health of the child was stated as the reason for the absence of a newborn on second hearing test in the survey. This factor cannot be influenced, but the parent with proper knowledge of NHS would bring his child to a hearing check as soon as their child's health condition allowed it. It is clear that parents' NHS education programs, at least during the pregnancy, would greatly improve the situation regarding the attendance to hearing controls.
Socioeconomic and demographic results of this study showed that most of the surveyed parents were from rural areas (64\%) with low monthly income. Distance from home to the place of control of hearing test was $39.4 \mathrm{~km}$ on average which imposed additional financial burden on parents. The distance from the test site and transportation problems in $8 \%$ of the cases in this study were cited as a reason for LTF and another $8 \%$ of the surveyed mothers reported that they forgot to bring their child to hearing control. In the literature, good data management and introduction of a monitoring system for mothers and children after discharge from the hospital are recommended. In this way, hearing test appointments of newborn babies can be reminded to the parents. There are many opportunities for reminding parents of appointments. Phone calls, short message services (SMS), and e-mails are some of the suggested options. For a good response of parents to hearing control and for achieving low LTF, the key factor is dedicated staff involved in NHS program ${ }^{33}$.

It seems that prematurity and the way of delivery (natural delivery or C-section), which in our study proven to be significantly different between the examined groups (NICU and WBN), were at the same time the reason why children were placed in NICU. Due to the fact that their child was placed in NICU, degree of concerns of the parents, in our study may be related to the significantly better knowledge about the treatment of children with hearing impairment. However, the amount of parental knowledge in both groups on other issues (about NHS, incidence of hearing loss in children, and $\mathrm{Cl}$ ) did not differ significantly in our study. Also, this study did not show that parents from any of the compared groups were more concerned about their child's hearing. Although certain differences between groups (NICU and WBN) were noted in this study, the fact that a child is placed in NICU after birth requires greater parental responsibility cannot be argued with certainty. 
Table 5. Table of recommendations.

$>$ Implementation of unique UNHS in all hospitals in the country with separate protocols for WBN (healthy newborns) and NICU.

$>$ Continuing education of staff involved in execution of NHS procedures which should reduce the number of false positive (refer) results of the first hearing test.

$>$ Continuing education of young couples and future parents about NHS, therapeutic possibilities for the children with hearing impairment and its benefits should reduce the number of children that would be lost to follow- up.

$>$ Development of good data management and introduction of a monitoring system for mothers and children after discharge from the hospital.

> Development of some of protocols for reminding the parents on appointments for the hearing control tests (e-mails, phone calls, short massage services - SMS etc.) to be.

UNHS: Universal Newborn Hearing Screening, WBN: Wellbaby Nursery, NICU: Neonatal Intensive Care Unit, NHS: Newborn Hearing Screening

\section{CONCLUSION}

UNHS should be implemented and performed with unique protocols in whole country. The main reason for default in follow-up in our study was caregiver's poor knowledge about this topic. With the intention of introducing the highest quality NHS, we conducted several studies from which the following recommendations emerged as described in Table 5. Further studies should be conducted in order to prepare, and implement UNHS in our country.

\section{REFERENCES}

1. Parving A. The need for universal neonatal hearing screening-some aspects of epidemiology and identification. Acta Paediatr. 2001;88:69-72. [CrossRef]

2. Olusanya BO. Highlights of the new WHO Report on Newborn and Infant Hearing Screening and implications for developing countries. Int J Pediatr Otorhinolaryngol. 2011;75:745-8. [CrossRef]

3. Attias J, Al-Masri M, Abukader L, et al. The prevalence of congenital and early-onset hearing loss in Jordanian and Israeli infants. Int J Aud. 2006;45:528-36. [CrossRef]

4. Smith R, Bale J, White K. Sensorineural hearing loss in children. Lancet. 2005;365:879-90. [CrossRef]

5. Rai N, Thakur N. Universal screening of newborns to detect hearing impairment-Is it necessary? Int J Pediatr Otorhinolaryngol. 2013;77:1036-41. [CrossRef]

6. ASHA Working Group on Loss to Follow-Up. Loss to follow-up in early hearing detection and intervention [Technical Report]. Available from: https://www.asha. org/policy/tr2008-00302/

7. Auerbach C, Mason SE, Zeitlin Schudrich WZ, Spivak L, Sokol H. Public health, prevention and social work: The case of infant hearing loss. Fam Soc. 2018;94:175-81. [CrossRef]

8. Yoshinaga-Itano C, Sedey AL, Coulter DK, Mehl AL. Language of early and later identified children with hearing loss. Pediatrics. 1998;102:1161-71. [CrossRef]

9. Grandori F, Lutman M. The European consensus development conference on neonatal hearing screening (Milan/ Italy May 15-16, 1998). Am J Audiol. 1999;8:19-20. [CrossRef]

10. Joint Committee on Infant Hearing. Year 2019 Position Statement: Principles and Guidelines for Early Hearing Detection and Intervention Programs. J Early Hear Detect Interv. 2019;4:1-44. [CrossRef]

11. Subbiah K, Mason CA, Gaffney M, Grosse SD. Progress in Documented Early Identification and Intervention for Deaf and Hard of Hearing Infants: CDC's Hearing Screening and Follow-up Survey, United States, 20062016. J Early Hear Detect Interv. 2018;3:1-7. [CrossRef]

12. Harrison M, Roush J, Wallace J. Trends in age of identification and intervention in infants with hearing loss. Ear Hear. 2003;24:89-95. [CrossRef]

13. Canale A, Favero E, Lacilla E, et al. Age of diagnosis of deaf babies: A retrospective analysis highlighting the advantage of newborn hearing screening. Int J Pediatr Otorhinolaryngol. 2006;70:1283-9. [CrossRef]

14. Durieux-Smith A, Fitzpatrick E, Whittingham J. Universal newborn hearing screening: A question of evidence. Int J Audiol. 2008;47:1-10. [CrossRef]

15. Zeitlin W, Auerbach C, Mason S, Spivak L, Reiter B. Factors related to not following up with recommended testing in the diagnosis of newborn hearing loss. Health Soc Work. 2017;42:24-31. [CrossRef]

16. Watkin P, McCann D, Law C, et al. Language ability in children with permanent childhood hearing impairment: the influence of early management and family participation. Pediatrics. 2007;120:694-701. [CrossRef]

17. White KR. Early hearing detection and intervention programmes: opportunities for genetic services. Am J Med Genet A. 2004;130:29-36. [CrossRef]

18. Spivak L, Sokol H, Auerbach C, Gershkovich S. Newborn hearing screening follow-up: factors affecting hearing aid fitting by 6 months of age. Am J Audiol. 2009;18:24-33. [CrossRef]

19. Nermin Hrncic. Identification of risk factors for hearing impairment in newborns: a hospital based study. Med Glas (Zenica). 2018;15:29-36. [CrossRef]

20. Yoshinaga-Itano C, Apuzzo ML. Identification of hearing loss after 18 months is not early enough. Am Ann Deaf. 1998; 143:380-7. [CrossRef]

21. Moeller MP. Early intervention and language development of children who are deaf and hard of hearing. Pediatrics. 2000;106:1-9. [CrossRef]

22. Swanepoel D, Störbeck C, Friedland P. Hearing detection and intervention in South Africa. Int J Pediatr Otorhinolaryngol. 2009;73:783-6. [CrossRef]

23. Van der Spuy T, Pottas L. Infant hearing loss in South Africa: Age of intervention and parental needs for support. Int J of Audiology. 2008;47:30-5. [CrossRef]

24. Olusanya BO, Swanepoel DW, Chapchap MJ, et al. Progress towards early detection services for infants with hearing loss in developing countries. BMC Health Serv 
Res. 2007;7:14. [CrossRef]

25. Hrncic N, Hatibovic H, Goga A, Hodžic Đ. Does an early discharge of a newborn influence the success of the newborn hearing screening in developing countries? A hospital based study. Med Glas (Zenica). 2019;16:209-15. [CrossRef]

26. Lupoli LM, Garcia L, Anastasio ART, Fontana AC. Time after birth in relation to failure rate in newborn hearing screening. Int J Pediatr Otorhinolaryngol. 2013;77:932-5. [CrossRef]

27. Scheepers LJ, Swanepoel de W, Roux TL. Why parents refuse newborn hearing screening and default on followup rescreening-a South African perspective. Int J Pediatr Otorhinolaryngol. 2014;78:652-8. [CrossRef]

28. Mukari S, Tan KY, Abdullah A. A pilot project on hospitalbased universal newborn hearing screening: lessons learned. Int J Pediatr Otorhinolaryngol. 2006;70:843-51. [CrossRef]

29. Ali L, Siddiq S, Khan MA, Maqbool S. A hospital-based universal newborn hearing screening programme using transient evoked otoacoustic emission (TEOAE). Pakistan
Pediatric J. 2000;24:117-25.

30. Olusanya BO. Follow-up default in a hospital-based newborn hearing screening programme in a low-income country. Child Care Health Dev. 2009;35:190-8. [CrossRef]

31. Spivak L, Sokol H. Beyond newborn screening: early diagnosis and management of hearing loss in infants. Adv Neonatal Care. 2005;5:104-12. [CrossRef]

32. Centers for Disease Control and Prevention (CDC). Identifying infants with hearing loss -United States, 1999-2007. MMWR Morb Mortal Wkly Rep. 2010;59:220-3. Available from: https://www.cdc.gov/ $\mathrm{mmwr} / \mathrm{preview} / \mathrm{mmwrhtml} / \mathrm{mm} 5908 \mathrm{a} 2 . \mathrm{htm}$

33. Friderichs N, Swanepoel D, Hall JW. Efficacy of a community-based infant hearing screening program utilizing existing clinic personnel in Western Cape, South Africa. Int J Pediatr Otorhinolaryngol. 2012;76:552-9. [CrossRef]

34. Swanepoel D, Almec N. Maternal views on infant hearing loss and early intervention in a South African community. Int J Audiol. 2008;47:44-8. [CrossRef] 